\title{
O DISTRITO DE TALCO DO PARANÁ, GÊNESE E CARACTERÍSTICAS DOS MINÉRIOS
}

\author{
Luciano Cordeiro de Loyola*
}

\author{
DISSERTAÇÃO DE MESTRADO - Programa de Pós-Graduação em Geologia - UFPR \\ DATA DE DEFESA: 28 ago. 2003
}

\begin{abstract}
Os depósitos do Distrito de Talco do Paraná estão encaixados em mármores dolomíticos integrantes das seqüências meta-vulcano-sedimentares do Grupo Itaiacoca, as quais apresentam também, quartzitos, filitos, metabásicas e metassiltitos. Estas litologias se dispõem com orientação NE-SW, entre dois complexos graníticos: Cunhaporanga e Três Córregos do ciclo Brasiliano. Todo o conjunto é cortado por um enxame de diques de microgabros do Cretáceo. O Grupo Itaiacoca está subdividido em três formações: Abapã, Água Nova e Bairro dos Campos. Nas duas últimas, encaixadas em mármores dolomíticos estão localizadas as jazidas de talco. Foram dois os processos genéticos que deram origem ao minério do Distrito de Talco do Paraná: metamorfismo regional dínamo-termal e hidrotermalismo. Nas minas do Distrito de Talco do Paraná encontram-se diversos tipos de minério, predominando os de cor branca, creme e rosa, variando de acordo com a associação mineralógica que apresentam. As principais impurezas são fragmentos de már-
\end{abstract}

more dolomítico, clorita, tremolita, sericita, quartzo, pirita, hematita e goethita. Existem minérios do Distrito de Talco do Paraná com o mineral talco microcristalino e também com o mineral talco macrocristalino. O Distrito de Talco do Paraná tem potencial para atender mercados mais exigentes, pois os minérios em geral apresentam características comerciais compatíveis com as aplicações mais nobres. Dentro de cada área os minérios são homogêneos, havendo necessidade de se efetuar uma melhor classificação de acordo com as exigências do mercado consumidor, apresentando garantias de qualidade e regularidade quanto à composição química, mineralógica e granulométrica, dentre outras. Neste trabalho diferenciaram-se duas áreas com características distintas: Ponta Grossa e Castro. As diferenças referem-se ao tamanho e freqüência de distribuição das jazidas e várias características do minério, tais como dimensão das lamelas individuais, lamelaridade, untuosidade, morfologia, presença de minerais acessórios e composição química. 